\title{
Original
}

\section{Qualitative and Quantitative Changes in Proteins in Rat Cerebral Cortex after Transient Focal Ischemia}

\author{
Isao Kitahara ${ }^{1)}$, Tamio Hagiwara ${ }^{2)}$, Minoru TaKeda ${ }^{2)}$, \\ Masataka IIDA $^{1)}$ and Kiyoshi Matsumoto ${ }^{1)}$
}

\begin{abstract}
To investigate the progression of neuronal damage after cerebral ischemia, the protein-alterations in rat cerebral cortex was qualitatively and quantitatively analyzed using a transient focal cerebral ischemia model. The cerebral cortex was fractionated into nuclear, mitochondrial, microsomal, and cytosolic fractions following transient ischemia. Proteins contained in each fraction were analyzed using sodium dodecyl sulfate polyacrylamide slab gel electrophoresis (SDS-PAGE). Two proteins (molecular mass: $67 \mathrm{kDa}$ and 80 $\mathrm{kDa}$ ) were markedly increased in the cytosolic fraction $16 \mathrm{hr}$ and 8 days following transient ischemia. Levels returned to baseline 2 weeks after lesioning. No significant differences were observed in the other fractions. The $67 \mathrm{kDa}$ protein was purified by ion-exchange chromatography followed by gel permeation chromatography and partial amino acid sequences were determined. As a result, a $67 \mathrm{kDa}$ protein that was increased following transient ischemia was identified as serum albumin. Moreover, in the cytosolic fraction of cerebral cortex following transient ischemia and subjection to immunoblot analysis using polyclonal antibody against rat whole serum. The results of this analysis revealed nine proteins, including the 67 and $80 \mathrm{kDa}$ proteins, derived from serum. Six of these proteins showed a similar pattern of transient increase $16 \mathrm{hr}$ and 8 days following transient ischemia. The $80 \mathrm{kDa}$ protein was identified as transferrin in terms of its molecular mass and cross-reactivity against an anti-human transferrin polyclonal antibody.
\end{abstract}

Key words: cerebral ischemia, serum proteins, proteins, albumin, transferrin, SDS-PAGE, rat, reperfusion

\section{Introduction}

Cerebral ischemic events such as infarctions induce rapid changes in the cerebral parenchyma, particularly in neurons. Diverse mechanisms are involved in these changes, and various types of information are transmitted and controlled. Cerebral ischemia causes delayed neuronal death ${ }^{1)}$ through mechanisms that include transsynaptic degeneration. The immediate early genes, such as $c$-fos, $c$-jun, and jun-B are markers of cell activation ${ }^{2-5)}$, and are induced by diverse stimuli including neurotransmitters. We therefore investigated the changes in brain proteins following ischemic injury, since ischemic damage may also trigger the induction of early genes.

\footnotetext{
1) Department of Neurosurgery, Showa University School of Medicine, 1-5-8 Hatanodai, Shinagawa-ku, Tokyo 142, Japan.

2) First Department of Biochemistry, Showa University School of Medicine
} 


\section{Materials and Methods}

Surgical procedure: Male Wistar rats $(300 \mathrm{~g})$ were allowed food and water ad lib. and housed in a structure with a $12-\mathrm{h}$ dark/light cycle at $22^{\circ} \mathrm{C}$. These rats were anesthetized with sodium pentobarbital $(20 \mathrm{mg} / \mathrm{kg}$, IP) $5 \mathrm{~min}$ prior to inducing general anesthesia with endotracheal intubation. The rats inhaled $0.5-1.0 \%$ halothane mixed with $20 \%$ oxygen and $80 \% \mathrm{~N}_{2} \mathrm{O}$ as an anesthetic supplement, and were respired mechanically during the procedure. Craniotomy was performed using the modified Tamura method ${ }^{6}$. The rats were fixed on a stereotaxic frame in the left lateral position. Except where indicated, the procedure was as follows: A $2 \mathrm{~cm}$ longitudinal, linear scalp incision was made along the midline of the orbito-meatal line on the right side of the head. The temporal muscle was cut sufficiently to expose the zygomatic arch after bipolar coagulation. A circular hole, $3 \mathrm{~mm}$ in diameter, was made in the right hemiskull with a dental drill and cold saline drip, additional bone was removed with a rongeur to expose the proximal middle cerebral artery (MCA). The bone removed in this way was placed in cold saline. In selected animals, the needletype sensor of a laser blood-flow meter was inserted into the burr hole, and gently placed on the dura mater above the ipsilateral cerebral cortex, to measure regional cerebral blood flow (rCBF). The pia mater was pulled away with a $22 \mathrm{G}$ needle that had been bent at the tip. Care was taken to preserve the cerebral cortex during craniotomy and monitoring of rCBF. A temporary Sugita aneurysm clip (No. 51; Mizuho-ika-kogyo Co. Inc., Tokyo, Japan), which had been modified to include a circle at the top, was applied to the right MCA above the rhinal fissure. After $30 \mathrm{~min}$ of ischemia, the bone flap was replaced and muscle and skin were sutured separately, layer to layer. Animals that excluded from the subsequent experiments were those that experienced major blood loss or required more than $20 \mathrm{~min}$ for successful production of ischemia, animals in poor condition after arousal from general anesthesia, and animals with seizures during 1 hour of observation after the treatment.

Cell fraction procedure: After inducing transient cerebral ischemia as described above, the right side of the cortex was considered ischemic, while the left was the non-ischemic control. After reperfusion of the ischemic region, animals were anesthetized by an intraperitoneal injection of $0.2 \mathrm{ml}$ of sodium pentobarbital and decapitated. Under a dissection microscope, the cerebral cortex was quickly extracted. The cerebral surface was washed with phosphate-buffered saline (PBS), and both the ischemic and non-ischemic portions of the specimen were prepared in a homogenization buffer using a teflon homogenizer. Each portion of the specimen was centrifuged at $1000 \mathrm{~g}$ for $10 \mathrm{~min}$, and $2 \mathrm{ml}$ of homogenization buffer was added to the precipitate, which was the nuclear fraction. The supernatant was then centrifuged at $15,000 \mathrm{~g}$ for an additional $20 \mathrm{~min}$, and $0.5 \mathrm{cc}$ of homogenization buffer was added to the precipitate. This was the mitochondrial fraction. Finally, the supernatant was centrifuged at $105,000 \mathrm{~g}$ for 1 hour, and $100 \mu \mathrm{l}$ of buffer was added to the precipitate, which was the microsomal fraction. The supernatant was the cytosolic fraction, and was subdivided into four fractions. Both the ischemic and non-ischemic portions were separated by sodium dodecyl sulfate polyacrylamide gel electrophoresis (SDS-PAGE) and were stained with Coomassie brilliant blue stain, protein changes were observed over time.

Purification and determination of the partial amino acid sequences of increased $67 \mathrm{kDa}$ protein after transient ischemia 
(1) Gel filtration chromatography: The cytosolic fraction prepared 16 hours following transient ischemia (approximately $4 \mathrm{ml}$ ) was concentrated by ammonium sulfate precipitation (final concentration: $75 \%$ saturation). Then, the precipitate was dissolved in $20 \mathrm{mM}$ Tris$\mathrm{HCl}(\mathrm{pH} 7.55)$. This fraction was subjected to gel permeation chromatography on tandemjointed TSK G3000SW $\times$ L $(7.5 \mathrm{~mm}$ I.D. $\times 30 \mathrm{~cm} \times 2)$ [Details are described in figure legends.]. Fractions that were obtained were checked by SDS-PAGE, and fractions containing $67 \mathrm{kDa}$ protein were pooled.

(2) Ion exchange chromatography procedure: Pooled fractions were then subjected to ion-exchange chromatography on a TSK DEAE-5PW $(7.5 \mathrm{~mm}$ I.D. $\times 15 \mathrm{~cm})$ [Details are described in figure legends.] and fractions containing the $67 \mathrm{kDa}$ protein were pooled. The $67 \mathrm{kDa}$ protein was nearly pure in this step.

(3) Peptide map and amino acid sequence analysis: The isolated $67 \mathrm{kDa}$ protein was dialyzed against $0.2 \mathrm{M} \mathrm{N}$-methyl morpholine-acetate buffer $(\mathrm{pH} 8.1)$ and digested with tosyl phenylalanine chloromethyl ketone (TPCK)-trypsin at $37^{\circ} \mathrm{C}$ for $12 \mathrm{hr}$. The tryptic products of digestion were separated using a reverse-phase column [Shodex C18-5A (4.6 mm I.D. $\times$ $25 \mathrm{~cm})]$. The partial amino acid sequences of peptide fragments obtained were analyzed using a solid-phase protein sequencer (model 6625; Milligen Biosearch).

Immunoblot analysis: The cytosolic fractions of cerebral cortex were separated by $10 \%$ polyacrylamide-SDS gels and electrophoretically trnasferred to a nitrocellulose filter. This filter was preincubated with $5 \%$ non-fat dry skim milk in Tris-buffered saline, $\mathrm{pH} 7.6$ containing $0.1 \%$ Tween 20 (TBS-T). Then it was incubated for $1 \mathrm{hr}$ with the specific antibody. After a washing with TBS-T, the filter was incubated with horse-radish peroxidase-conjugated anti-rabbit IgG antibody for $1 \mathrm{hr}$. A rabbit anti-rat whole serum antibody was used as the primary antibody. For the detection of transferrin, rabbit anti-human transferrin anti-serum was used as the first antibody. Immunoreactive bands were detected uisng an Amersham ECL detection kit (ECL detection kit; Amersham).

\section{Results}

Analysis of regional cerebral blood flow ( $\mathrm{rCBF}$ ) data: Regional cerebral blood flow $(\mathrm{rCBF})$ on the lesioned side, monitored continuously during the procedure in selected animals, was reduced immediately following MCA clipping. The relative decrease in rate after 5 to $30 \mathrm{~min}$ of ischemia was a convenient measure of rCBF. The rCBF in the parietal cortex (close to the MCA) fell to $26.30 \% \pm 4.12 \%$ (mean $\pm \mathrm{SE}, \mathrm{n}=5$ ) of the preischemic value after $5 \mathrm{~min}$ of clipping. However it rose slightly to $71.3 \% \pm 5.33 \%$ (mean $\pm \mathrm{SE}, \mathrm{n}=5$ ) of the preischemic value after $30 \mathrm{~min}$, while the clip was still in place (Fig. 1). There was no mortality and the reduction in $\mathrm{rCBF}$ in each region was reproducible (Student's $t$ test $\mathrm{p}<0.01$ ).

Changes in rat cerebral cortex proteins following ischemia and reperfusion: At various times $(0,1,2,4,8,16$ hours, 1, 2, 4, 8, 16, 30 days) after the induction of ischemia and reperfusion, the proteins in the cerebral cortex were compared by SDS-PAGE. We observed an increase in two proteins in the cytosol fraction of the ischemic cortex compared with the non-ischemic control. Changes were noted primarily at approximately 67 and $80 \mathrm{kDa}$. However, the other fractions, no changes over time were observed, and there were no differences between the ischemic and non-ischemic portions. These proteins were first detected 8 hours following reperfusion. They had a biphasic time course, with peaks at 16 hours and 8 days. By the 15th and 30th days, their levels had returned to normal (Figs. 2 and 3). 


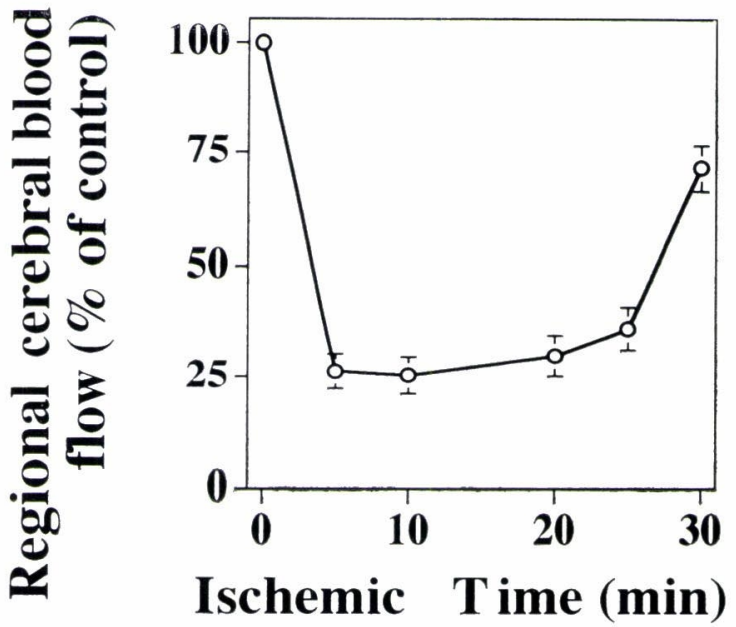

Fig. 1. Regional cerebral blood flow in the lesioned parietal cortex measured by laser bloodflow meter 5 to $30 \mathrm{~min}$ after clipping the middle cerebral artery.

\section{Mr.(kDa)}

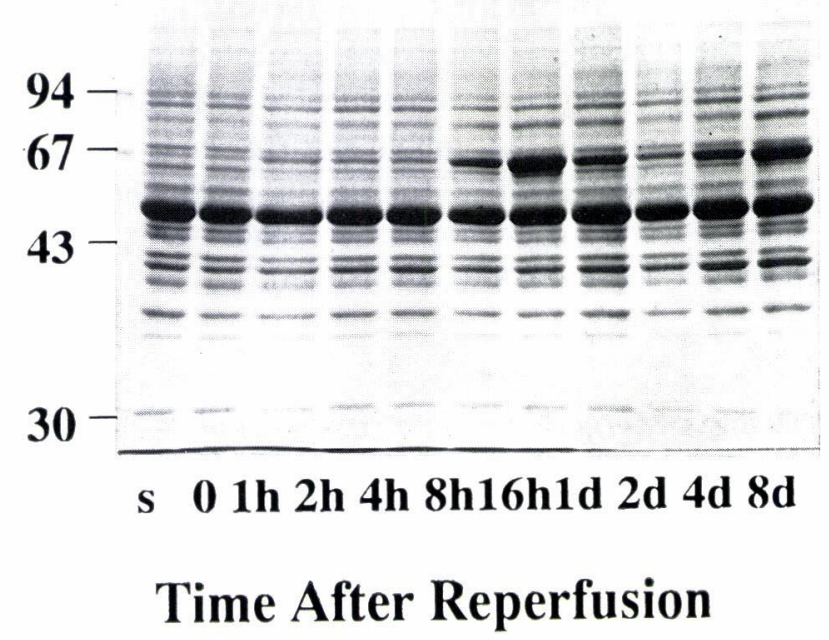

Fig. 2. Qualitative and quantitative protein-alteration in the cytosolic fractions of cerebral cortex after transient focal ischemia. The cytosolic proteins (about $25 \mathrm{mg}$ of protein) were separated on SDS-polyacrylamide slab gel. S: sham operated (times indicate reperfusion period after transient ischemia) ( $h$ : hours, d: days).

Identification of the $67 \mathrm{kDa}$ protein:

(1) Gel filtration: SDS-PAGE revealed that the $67 \mathrm{kDa}$ target protein was detected at fractions No. 14 and 15 (Fig. 4A), corresponding to an elution time of 14-15 min on the TSK G3000SW $\times$ L gel filtration column (Fig. 4B).

(2) Ion exchange: SDS-PAGE revealed that the $67 \mathrm{kDa}$ target protein was detected at fractions No. 25, 26, and 27 (Fig. 5A), corresponding to an elution time of 25-27 min on the DEAE-5PW column (Fig. 5B). 


\section{\% of Control}

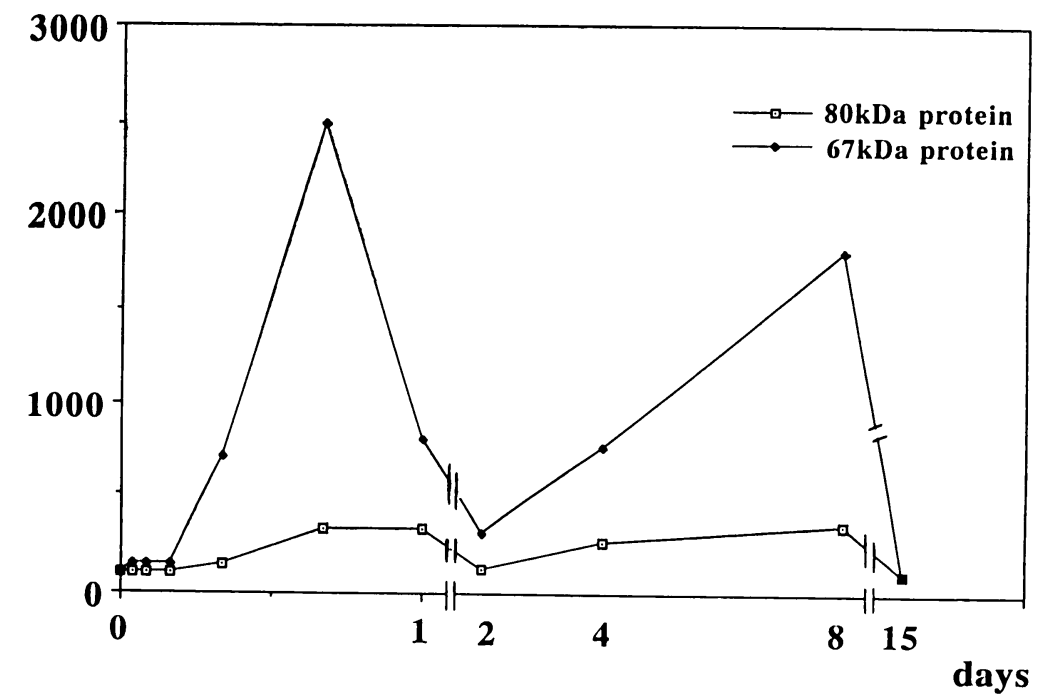

Fig. 3. Time-course of quantitative alterations of $67 \mathrm{kDa}$ and $80 \mathrm{kDa}$ proteins. To measure the amount of $67 \mathrm{kDa}$ and $80 \mathrm{kDa}$ proteins, Coomassie brilliant blue-stained gel (Fig. 2) was subjected to densitometric scanning. Each value represents the relative amount of $67 \mathrm{kDa}$ and $80 \mathrm{kDa}$ proteins compared with the amount of these proteins in the sham-operated cytosol.

(3) Peptide map and amino acid sequence analysis: The $67 \mathrm{kDa}$ protein was processed through gel filtration and ion exchange. After isolating and purifying the protein, about 58 fragments were obtained by trypsin digestion (Fig. 6A). The results of amino acid sequence analysis of the major peptide fragments are shown in Fig. 6A. By analyzing the amino acid sequences of the fragments, the protein was identified as albumin ${ }^{7}$ (Fig. 6B).

Immunoblot analysis by anti-rat whole serum antibody: Immunoblot analysis with antirat whole serum antibody revealed nine proteins as indicated by molecular weight (bands A, B, C, D, E, F, G, I and K) (Fig. 7A). S (Fig. 7) indicates rat whole serum. Rat whole serum were reacted with rat serum proteins. Albumin band was F. Transferrin band was D. Five proteins (bands A, C, D, E and G in Fig. 7A) on the ischemic side illustrated a biphasic time course similar to albumin. Protein C (Fig. 7A) exhibited a pattern similar to albumin, but totally disappeared on the 2nd day. Proteins B and I (Fig. 7A) were found only on the 4th and 8th days. Proteins H, J, L (Fig. 7A) were ambiguous. Protein K was found on the 2 nd, 4 th and 8 th days. Protein $M$ exhibited a continuous pattern throughout the experiment. There was almost no evidence of serum proteins on the non-ischemic side (Fig. 7B).

Immunoblot analysis using anti-transferrin antiserum: Immunoblot analysis using rabbit anti-human transferrin antiserum revealed that the $80 \mathrm{kDa}$ protein was transferrin (Fig. 8A). $\mathrm{S}$ (Fig. 8) was rat whole serum. Rat whole serum was reacted with $80 \mathrm{kDa}$ band. Transferrin was not as sensitive as albumin, but showed the same biphasic pattern, with peaks at 16 hours and 8 days. There was almost no evidence of transferrin on the non-ischemic side (Fig. 8B). Other bands were found in both the ischemic and non-ischemic portions. Because the other bands were not seen in the rat whole serum, these were considered non-specific 


\section{A Mr.(kl)a)}

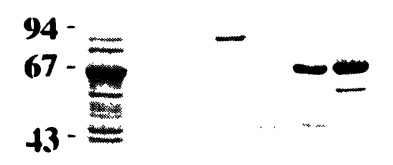

20.1

Cy 101112131415161718192021222324252627282930

Fraction Number

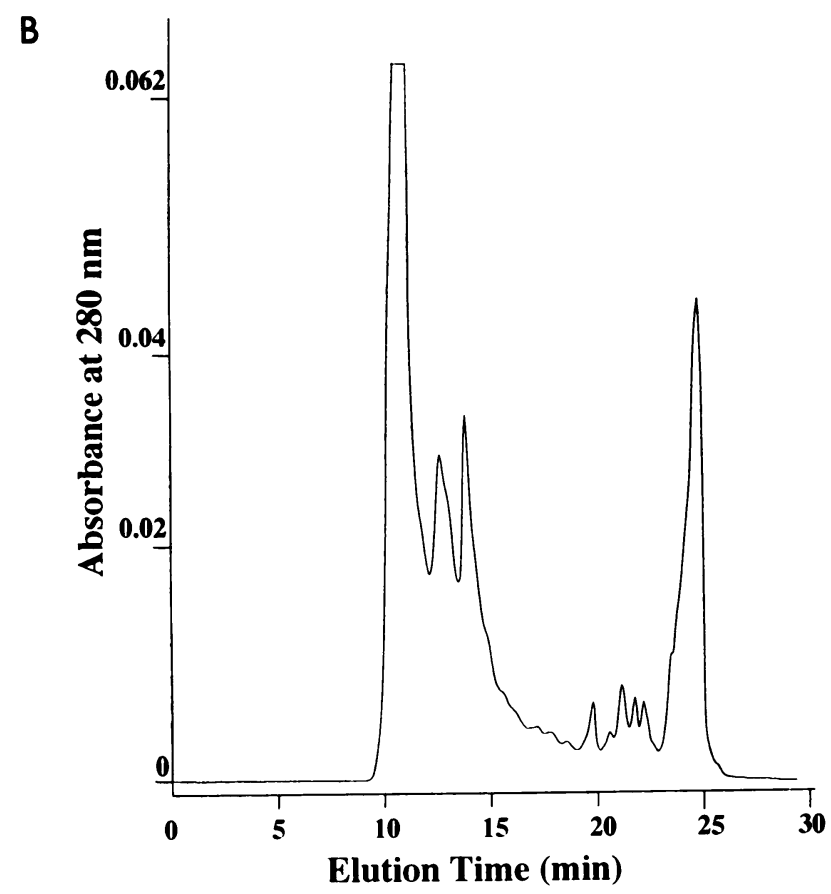

Fig. 4. Gel permeation chromatography of cytosolic proteins. The cytosolic proteins (about $50 \mathrm{mg}$ ) prepared at $16 \mathrm{hr}$ after transient ischemia were concentrated by ammonium sulfate-precipitation (final $75 \%$ saturation) and applied to tandem-jointed TSK G3000SWXL column (7.5 mm I.D. $\times 30 \mathrm{~cm} \times 2$, TOSO, JAPAN). The proteins were eluted with $20 \mathrm{mM}$ Tris- $\mathrm{HCl}(\mathrm{pH} 7.5)$ at $1.0 \mathrm{ml} / \mathrm{min}$ flow rate and the fractions were collected in $1.0 \mathrm{ml} /$ tube. Proteins contained in each fraction were analyzed by Coomassie brilliant blue-staining following SDS-PAGE.

(A) SDS-PAGE analysis of fractionated proteins. Cy: cytosol.

(B) Elution profile on TSK G3000SWxL column.

bands.

\section{Discussion}

Cerebral edema is the typical pathologic mechanism of injury in our model of transient cerebral ischemia. Decreases in the intracellular energy production may cause cytotoxic edema due to metabolic disorders involving $\mathrm{Na}^{+}, \mathrm{K}^{+}$, and $\mathrm{Ca}^{2+8}$. Serum protein is released 


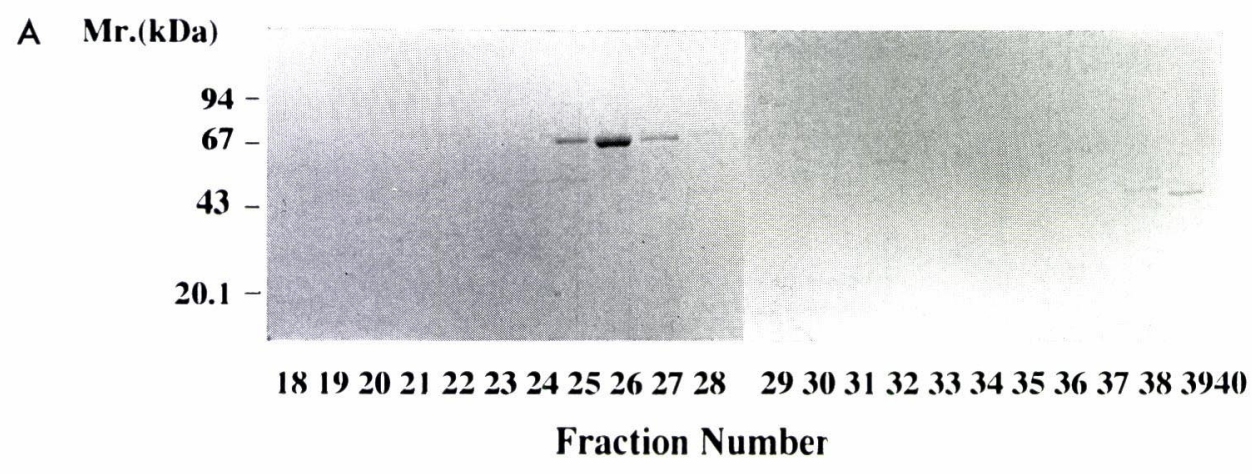

B

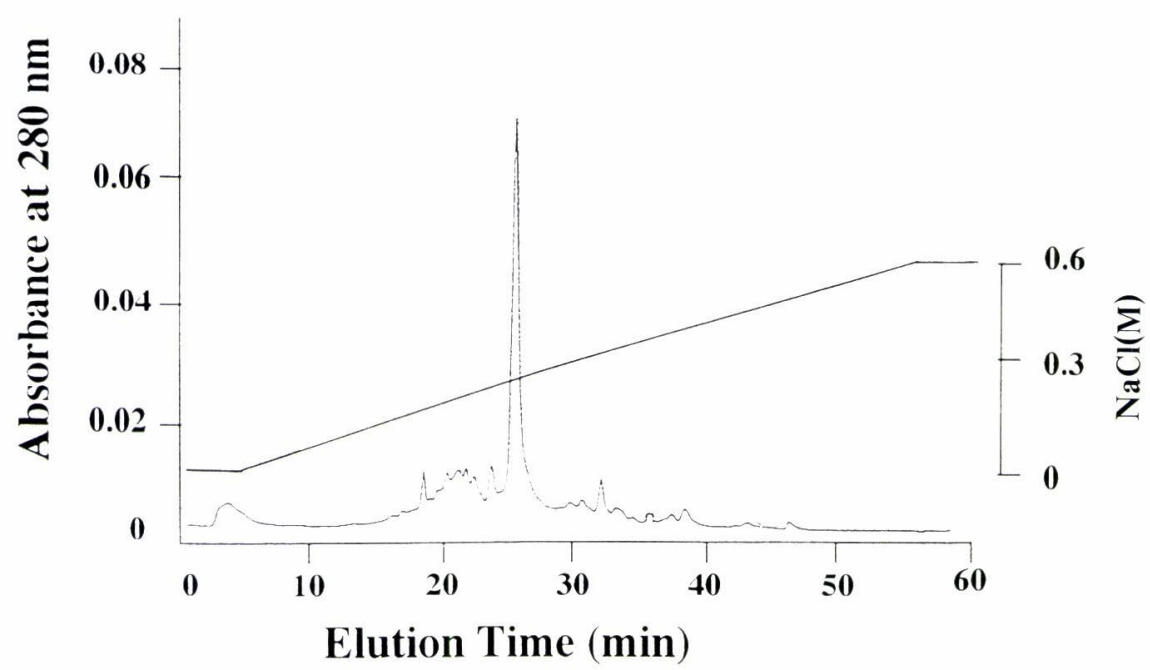

Fig. 5. DEAE-5PW ion exchange chromatography. The partially purified $67 \mathrm{kDa}$ protein (Fig. 2, Fraction No. 14 and 15) on a TSK DEAE-5PW column (7.5 mm I.D. $\times$ $15 \mathrm{~cm}$, TOSO, JAPAN). The proteins were eluted by a linear gradient to $\mathrm{NaCl}$ (between 0 and $0.6 \mathrm{M}$ ) in a $20 \mathrm{mM}$ Tris- $\mathrm{HCl}(\mathrm{pH} 7.5)$ and the fractions were collected in $1.0 \mathrm{ml} /$ tube.
(A) SDS-PAGE analysis of fractionated proteins.

(B) Elution profile on a TSK DEAE-5PW column.

due to the breakdown of the blood-brain barrier, and vasogenic edema occurs with some delay $^{9)}$. Using a rat model of focal cerebral ischemia, we studied the changes in brain proteins in order to identify mechanisms of cerebral ischemic injury.

Two cytosol proteins extracted from ischemic cortex exhibited an increase compared with levels in non-ischemic cortex. These proteins were initially observed 8 hours following reperfusion, and exhibited peaks at 16 hours and 8 days. However on the 15 th and 30th days after the ischemic event, the electrophoretic pattern reverted to preischemic levels.

Among proteins whose expression profile changed following the ischemic events, the band at $67 \mathrm{kDa}$ was most prominent. This protein was isolated and purified using gel filtration and ion exchange chromatography. It was digested with TPCK-trypsin, and the amino acid sequence was identified as albumin. 


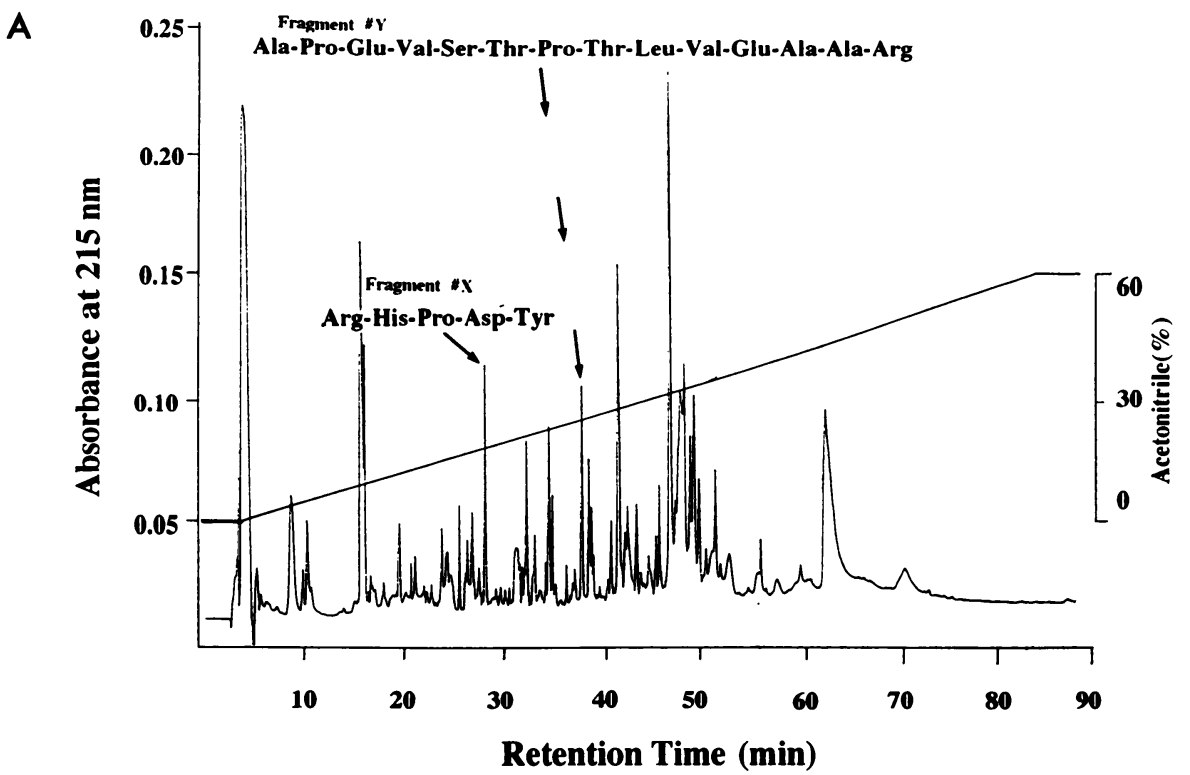

B 332

Rat albumin

Fragment \#X

of $67 \mathrm{kDa}$ protein
YEYSRRHPDYSVSLLLR

\section{RHPDY}

\section{Rat albumin}

Fragment \#Y

\section{YTQKAPEVSTPTLVEAARNLGR}

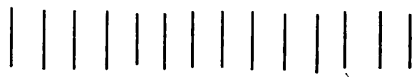

APEVSTPTLVEAAR

\section{of $67 \mathrm{kDa}$ protein}

Fig. 6. Partial amino acid sequences of $67 \mathrm{kDa}$ protein. Purified $67 \mathrm{kDa}$ protein (Fig. 5, Fraction No. 26, about $200 \mathrm{mg}$ of protein) was digested with TPCK-trypsin and the triptic digests were separated on a reverse-phase column (Shodex C18-5A, $4.6 \mathrm{~mm}$ I.D. $\times 25 \mathrm{~cm}$, SHOWA DENKO K.K., JAPAN) by a linear gradient of acetonitrile (between 0 and $60 \%$ ) in a $0.05 \%$ trifluoroacetic acid.

(A) Peptide map determined partial amino acid sequences of a trypsin-digested $67 \mathrm{kDa}$ protein.

(B) Homology analysis obtained partial amino acid sequences of $67 \mathrm{kDa}$ protein. Homology search was performed by a computer-supported analysis using GENETYX software (GENETYX, USA). 


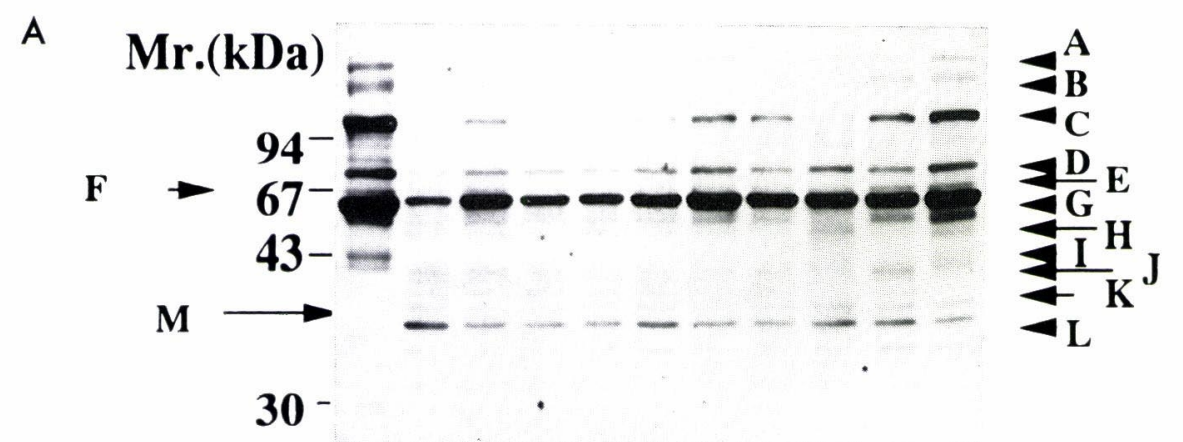

\section{s 0 1h2h4h8h16h1d2d4d8d}

\section{Time After Reperfusion}

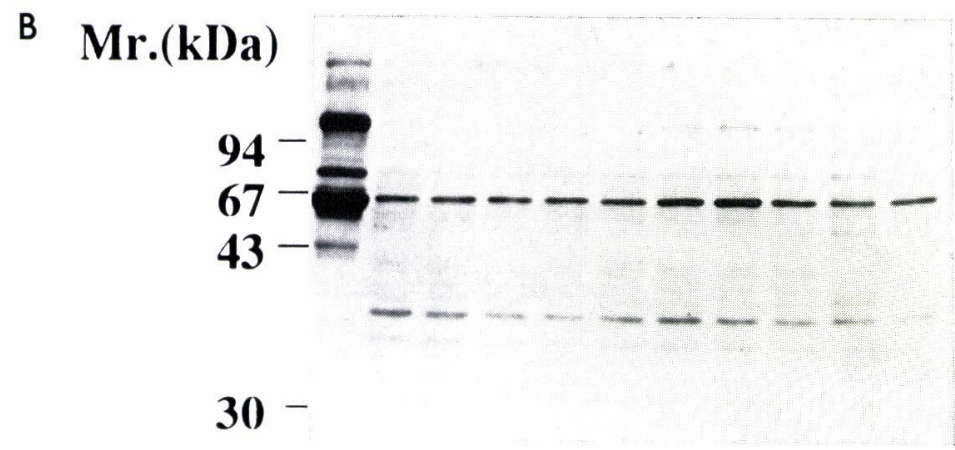

\section{s 0 1h2h4h8h16h1d2d4d8d}

\section{Time After Reperfusion}

Fig. 7. Immunoblot analysis using anti-rat whole serum antiserum. Cytosolic fractions prepared from cerebral cortex of the operation side (A) and the control side (B). $\mathrm{S}$ : rat whole serum (times indicate reperfusionperiod after transient ischemia) (h: hours, d: days).

A: MW about 450, B: MW about 300, C: MW about $150, \mathrm{D}:$ MW about $80, \mathrm{E}$ : MW about 70, F: MW about 67, G: MW about 56, H: MW about 50, I: MW about 43, J : MW about 40, K: MW about 38, L: MW about 35 .

In a gerbil model of unilateral cerebral hemisphere ischemia, Ito et al. ${ }^{10)}$ have found that albumin increased from 5-6 hours to 3 days once the circulation resumed following intervals of transient cerebral ischemia lasting for $1 / 2,1,3$, and 6 hours. On the other hand, in the case of an ischemic event lasting 3 hours or more, edema increased far beyond the increase associated with permanent ischemia 3 hours following circulation resumption ${ }^{10)}$. In addition, a marked extravasation of serum albumin was noted that was seen in cases of permanent ischemia. In a cat model of middle cerebral artery occlusion ${ }^{11)}$, similar findings have been reported by Kuroiwa et al. They used conventional immunohistochemical methods 
A

Mr.(kDa)

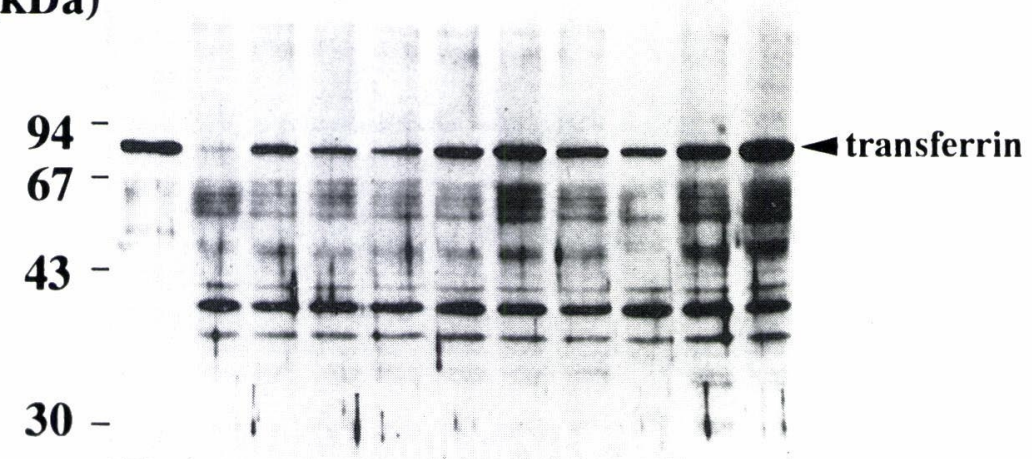

s 0 1h2h4h8h16h1d2d4d8d

\section{Time After Reperfusion}

\section{B Mr.(kDa)}

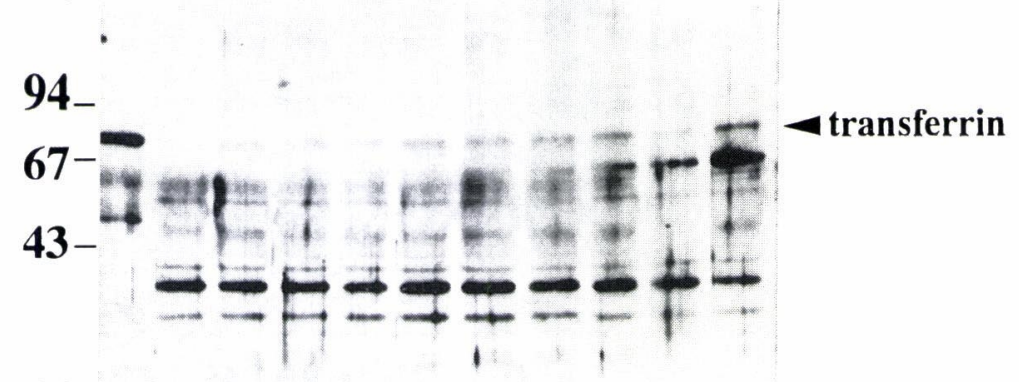

30-

\section{s 0 1h2h4h8h16h1d2d4d8d}

\section{Time After Reperfusion}

Fig. 8. Increased $80 \mathrm{kDa}$ protein after transient ischemia is a serum transferrin. The cytosolic proteins (about $25 \mathrm{mg}$ of protein) were separated on SDS-polyacrylamide slab gel (same as Fig. 2) and electrophoretically transferred to a nitrocellulose filter. A transferrin was detected with rabbit anti-human transferrin antiserum. The arrowhead indicates the position of the transferrin. Cytosolic fractions prepared from cerebral cortex of the operation side (A) and the control side (B). S: rat whole serum (times indicate reperfusion period after transient ischemia) (h: hours, d: days).

to show the extent of extravasation, while in the present study SDS-PAGE methods revealed cytosol albumin concentrations of $6-8 \mathrm{mg} / \mathrm{g}$ cerebral cortical tissue. Together, these results demonstrate a marked increase, not only in the area leaking albumin, but also in the amount of albumin within the area.

We observed a biphasic time course of enhanced protein expression, the mechanism of which may involve the following steps: Hyperemia (luxury perfusion) occurs in an entire 
ischemic lesion within a short time when circulation is resumed after transient ischemia. To compensate, the permeability of the blood-brain barrier temporarily increases and this enhanced permeability has a biphasic time course ${ }^{12-14}$. In our experiments, we observed peaks at 16 hours and 8 days. Thus, the first peak may have been due to changes in the blood-brain barrier, secondary to luxury perfusion, which begin about the time when albumin is absorbed by extra-cellular fluid. The second peak appears gradually thereafter with some deviation. Since degeneration is trans-synaptic, information is transmitted across the synaptic cleft to influence proteins. From the immunohistochemical viewpoint, this is manifested by the appearance of the immediate early gene $c$-fos in the parietal cortex $10 \mathrm{~min}$ following occlusion of the MCA. c-fos demonstrates a peak at $60 \mathrm{~min}$, and disappears after $120 \mathrm{~min}$. In the cingulate cortex, $c$-fos appears after $10 \mathrm{~min}$, and peaks at $60 \mathrm{~min}$, but is still detectable after $120 \mathrm{~min}^{2}$. These differing effects on the expression of immediate early genes may be related to the biphasic time course in serum proteins. The information of the immediate early genes may exert an influence on protein due to the difference of sites in this case.

Since the $67 \mathrm{kDa}$ protein appears to be albumin, the other increased proteins also may be derived from the serum. Immunoblot analysis, using anti-rat whole serum antibody, revealed nine serum proteins. The six serum proteins including albumin had a biphasic time course to similar to that of albumin. Two proteins were found only on the 4th and 8th days. One protein was found on the 2 nd, 4 th and 8 th days. Since the time course of bands B, I, $\mathrm{K}$ differed from that of albumin, they were not included among the serum-derived proteins. Protein bands H, J, L (Fig. 7A) were ambiguous and band $M$ revealed no changes and hence was considered non-specific.

We also focused our attention on the identification of the $80 \mathrm{kDa}$ band, using anti-human transferrin antiserum. Immunoblot analysis revealed that one of the bands was transferrin. Among them, the most sensitive was albumin, followed by band C (Fig. 7A) or transferrin. Thus it appears that selectivity is not determined simply by molecular weight. All bands returned to baseline between the 15 th and 30 th days. The mechanism by which proteins are absorbed is usually explained as follows: Proteins pass through extra vascular spaces (Virchow-Robin spaces) or while substance through ventricles and are draining to the cerebrospinal fluid, endocytosed by microglia, or partially enter nerve cells ${ }^{15)}$. The ischemic lesion then subsides. When these proteins enter nerve cells, swelling may occur. Thus it appears that changes over time in various proteins including albumin caused by transient ischemia, and the increase of nine proteins including albumin may be important contributing factors of acute and chronic changes in internal conditions due to ischemia. Brain ischemic injury causes the brain parenchyma to changed the permeability of the blood-brain barrier. Serum proteins including albumin appear to be good markers in brain ischemia.

\section{References}

1) Kirino $\mathrm{T}$ : Delayed neuronal death in the gerbil hippocampus following ischemia. Brain Res, 239: 57-69 (1982)

2) Shimazu M, Mizushima H, Sasaki K, Arai Y, Matsumoto K, Shioda S and Nakai Y: Expression of c-fos in the rat cerebral cortex after focal ischemia and reperfusion. Brain Res Bull, 33: 689697 (1994)

3) Uemura Y, Kowall NW and Beal MF: Global ischemia induces NMDA receptor-mediated c-fos expression in neurons resistant to injury in gerbil hippocampus. Brain Res, 542: 343-347 (1991)

4) Uemura Y, Kowall NW and Moskowize MA: Focal ischemia in rats causes time-dependent expression of c-fos protein immunoreactivity in widespread regions of ipsilateral cortex. Brain Res, 552: 
99-105 (1991)

5) Wessel TC, Jon TH and Volpe BT: In situ hybridization analysis of c-fos and c-jun expression in the rat brain following transient forebrain ischemia. Brain Res, 567: 231-240 (1991)

6) Tamura A: Animal model of cerebral ischemia. Shinkei Kenkyu no Shinpo, 35: 73-82 (1991) (in Japanese)

7) Sargent TD, Yang $\mathbf{M}$ and Bonner $J$ : Nucleotide sequence of cloned rat serum albumin messenger RNA. Proc Natl Acad Sci USA, 78: 243-246 (1981)

8) Siesjö BK: Review article. Pathophysiology and treatment of focal cerebral ischemia. Part I. Pathophysiology. J Neurosurg, 77: 169-184 (1992)

9) Katzmann R, Clasen CR, Klatzo I, Meyer JS, Pappius HM and Waltz AG: Report of joint committee for stroke resources IV. Brain edema in stroke. Study group on brain in stroke. Stroke, 8: 512-540 (1977)

10) Ito U, Ohno K, Nakamura R, Suganuma F and Inaba Y: Brain edema during ischemia and after restoration of blood flow. Measurement of water, sodium, potassium content and plasma protein permeability. Stroke, 10: 542-547 (1979)

11) Kuroiwa T, Shibutani $\mathbf{M}$ and Okeda $\mathbf{R}$ : Blood-brain barrier disruption and exacerbation of ischemic brain edema after restoration of blood flow in experimental focal cerebral ischemia. Acta Neuropathol (Berl), 76: 62-70 (1988)

12) Kuroiwa T, Ting P, Martinez $\mathbf{H}$ and Klatzo $\mathbf{I}$ : The biphasic opening of the blood-brain barrier to proteins following temporary middle cerebral artery occlusion. Acta Neuropathol (Berl), 68: 122129 (1985)

13) Preston E, Sutherland G and Finsten A: Three openings of the blood-brain barrier produced by forebrain ischemia in the rat. Neurosci Lett, 149: 75-78 (1993)

14) Suzuki R, Yamaguchi T, Kirino T, Orzi, F and Klatzo I: The effects of 5 minute ischemia in Mongolian gerbils: I. Blood-brain barrier, cerebral blood flow, and local cerebral glucose utilization changes. Acta Neuropathol (Berl), 60: 207-216 (1983)

15) Ito U, Go KG, Walker JT, Spatz $\mathbf{M}$ and Klatzo I: Experimental cerebral ischemia in Mongolian gerbils III. Behavior of the blood-brain barrier. Acta Neuropathol (Berl), 34: 1-6 (1976)

[Received November 22, 1994: Accepted December 14, 1994] 